\title{
Macbeth and the Passions' "Proper Stuff"
}

\author{
Zenón Luis Martínez \\ Universidad de Huelva
}

\begin{abstract}
This essay examines early modern conceptions and representations of the passions in relation to issues of selfknowledge in texts ranging from Renaissance psychology to Shakespearean tragedy -with a particular focus on Macbeth. Considered in essence processes of the mind, the passions were believed to manifest themselves through material symptoms such as bodily effects, facial gestures and discourse. Accordingly, the early modern philosophy of man saw in the study of these material manifestations a vehicle to access the soul. By tracing the methodologies for translating the material side of human experience -words, gestures, bodily sensations and signals- into less material truths, early modern philosophy and theatre explored the certainties about inwardness as a necessary dimension of the self, as well as the uncertainties about the ultimate essence of such interiority. In this, Shakespeare's Macbeth, for its constant focus on outward appearance and rhetoric, stresses the need to focus on matter as a vehicle to explore interiority. And yet -and in keeping with the principles of earlier Renaissance humanists- the play acknowledges the utter impossibility to know the ultimate essence of the inward self.
\end{abstract}

KEYWORDS: Renaissance tragedy, Shakespeare studies, Macbeth, humanism, rhetoric, (the) passions of the mind.

\footnotetext{
* A former version of this essay was presented at the International Shakespeare Conference (Stratford-upon-Avon, 2006) as part of the seminar "The Possibility of Awareness." I thank Robin Headlam Wells, Robyn Bolam, and Madhavi Menon for responses and comments. I have also benefited from Fernando Navarro's not precisely small Latin.
}

\author{
C. ederi 20 (2010: 71-101) \\ https://doi.org/10.34136/sederi.2010.4
}


How aware can one be of one's passions? How aware can one be of others' passions? What follows explores the relevance of these questions for establishing notions of self-knowledge in texts ranging from Renaissance psychology to Shakespearean tragedy -with a particular focus on Macbeth. The aim is not just to assess key aspects of early modern representations of the passions -namely, their ambivalent nature as motions affecting body and mind, their resilience to inspection and interpretation, or the importance of language, rhetoric and gesture as vehicles for their dramatic expression. This essay also takes issue with certain premises of the so-called "corporeal turn" in recent Shakespeare studies. ${ }^{1}$ By stressing the pre-eminence of the body, these studies have often interpreted the dualism of body and soul as a critical misrepresentation of the early modern experience of the self. By contrast, I contend that Renaissance notions of the self were essentially dualistic. Considered in essence processes of the mind, the passions were believed to manifest themselves through material symptoms such as bodily processes, facial gestures and discourse. In keeping with this, the early modern philosophy of man saw in the study of these material manifestations a vehicle to access the soul. Inscrutable in substance, but accessible through its functions, the inward self was regarded as a mystery worthy of examination. By tracing the methodologies for translating the material side of human experience -words, gestures, bodily sensations and signals- into less material truths, this essay explores, in theory and in theatre, the early modern certainties about inwardness as a necessary dimension of the self, as well as the uncertainties about the ultimate essence of such interiority. ${ }^{2}$

\footnotetext{
${ }^{1}$ I borrow the phrase from Baumbach (2008:13-14), who derives it from Elam (1996:143), and provides several useful bibliographical instances in footnote.

2 My study thus departs from those critical attempts to refute interiority as constitutive of the Shakespearean tragic self, with special reference to Hamlet. A locus classicus is Barker's affirmation that "interiority remains, in Hamlet, merely gestural" (1984:36), an argument that this paper takes issue with. Other recent instances are Cefalu (2004:145-172), who contests "impressionistic 'inwardist" readings of Shakespeare (148), or Paster (2004a), more amply discussed below. In this sense, my study tallies, in spite of differences, with that of Maus, whose project explores "the afflictions and satisfactions that attend upon the difference between an unexpressed interior and a theatricalized exterior" (1995:2). My view of Renaissance notions of the inner self is basically coincident with Headlam Wells (2005). Beyond the theatre, and before the advent of Cartesian conceptions, the concern with the differences between
} 


\section{Know thy self}

Commenting on the uses of history, Juan Luis Vives wrote in De Tradendis Disciplinis (1531) that "those things that are contained in our natures never change, such as the causes of the affections of our minds, and their actions and effects, and that is more important for us to know than how men in Antiquity erected buildings, or how they dressed." An affirmation that leads him to ask:

What greater prudence is there than to know how and what the human passions are: how they are roused, how quelled? To know also what influence they can bring to bear on the commonwealth, their motivating forces, how they can be contained, healed, put aside or, on the other hand, inflamed and fomented, whether in others or ourselves? What can be more expedient either for the ruler of a city or for any of his subjects to know? And what can be more delightful, what more conducive to the most fruitful kind of prudence? ${ }^{3}$

Vives's point is eminently pragmatic: as a vehicle to the self, knowing one's passions brings not only ethical rewards but also political advantages. This must have justified Niccolò Machiavelli's similar preoccupations a few years earlier, as he reminded his readers -here via a mid seventeenth-century English translator- that "every man may come to see what thou seemest, few come to perceive what thou art." In a similar vein the English humanist Thomas Newton translated a well-known adage in Cicero's Somnium Scipionis thus: "Neither art thou that which thy outward form and shape declareth; but the mind and soul of every man is he, and not that figure and shape which may be pointed and showed with the

outward and inward selves has a long tradition in Western philosophy. As David Aers reminds us, "the whole medieval penitential tradition involves a fundamental and perfectly explicit distinction between inner and outer, between that which is within and passes show and that which is without, the external act" (1992:85). On the inner self see also Taylor (1989:esp. 111-142).

3 "Sed illa tamen nunquam o mutantur, quae natura continentur: nempe causae affectum animi, eorumque actiones, \& affecta, quod est longe conducibilius cognoscere, quam quomodo olim vel aedificabant, vel vestiebant homines antiqui. Quem enim maior est prudentia, quam scire, quibus ex rebus, qui hominum affectus vel conciantur, vel sedantur? Affectus porro illi quae adferant momenta in republica, quos motus, quamadmodum continendi, sanandi, tollendi, aut contra exagitandi, \& confondendi sive in aliis, sive in nobis ipsis?" (Vives 1612:350). The translation is Foster Watson's (1913:232). 
finger." Which he glossed marginally: "A man is his mind." ${ }^{4}$ At stake here is also the discontinuity of inward substance from outward appearance. The English Jesuit Thomas Wright, in his then widely read and now re-discovered The Passions of the Minde in Generall, argued that "as the motions of our Passions are hid from our eyes, so they are hard to be perceiued" $\left(1604: \mathrm{D}_{7}^{\mathrm{r}}\right)$. The emphasis is once again the opacity to the senses of the operations of our minds.

These statements show not only the practical importance of selfawareness and awareness of others, but also the intellectual assurance that the inward self, whose essence was conceived of as separable from a universe of outward materiality, was the ultimate target of this kind of knowledge. The insufficiency of our senses in our attempts to access the self sustained the Renaissance principle nosce teipsum. For Christian humanists, self-knowledge was a high ethical aspiration of the rational soul, whose search for truth comprised the elucidation of those processes originating in the human mind and body, and conditioning action and behaviour. ${ }^{5}$ For Wright, his treatise of the passions

comprehendeth the chiefe obiect that all Philosophers aimed at, wherin they placed the most of their felicitie, that was Nosce teipsum, Know thy selfe: the which knowledge principally consisteth of a perfit experience euery man hath of himselfe in particular, and an vniuersall knowledge of mens inclinations in common [...]. (Wright $1604: \mathrm{B}^{\mathrm{v}}-\mathrm{B}_{4}{ }^{\mathrm{r}}$ )

The passions were understood as motions or perturbations occurring between the material acts of the senses and the nonmaterial processes of the rational soul (Wright 1604: $\mathrm{B}_{4}{ }^{\mathrm{r}}$ ). Their centrality to a theory of the self was justified by this liminal nature and its implications for the spiritual history of humankind: since the corruption of reason by the passions was a condition of the Fall, the

\footnotetext{
${ }^{4}$ Machiavelli (1640:111), and Cicero (1577:fol.130) are both quoted in Soellner (1972:33, 9-10).

${ }^{5}$ In Sir John Davies' words in his poem Nosce Teipsum: "First in mans minde we finde an appetite / To learne and know the truth of euerie thing, / Which is connaturall, and borne with it, / And from the Essence of the Soule doth spring." This stanza is marginally glossed as "Reason. Drawne fro[m] the desire of knowledge" (1599: $\mathrm{H}_{4}{ }^{\mathrm{v}}$ ). Davies describes pre-lapsarian reason as an innocent but all-seeing faculty: "And when their reasons eye was sharp and cleere, / And (as an Eagle can behold the Sunne,) / Could haue approch't th'eternall light as neere, / As the intellectuall Angels could haue done" $\left(\mathrm{Bi}^{\mathrm{r}}\right)$.
} 
neo-Stoic doctrine of self-knowledge meant regaining for the rational soul awareness and control over those perturbations of the sensitive soul. $^{6}$

Renaissance self-knowledge was hence an attempt to police the relations between the outward and inward nature of human beings. Awareness of the contiguity of body and soul, and of the continuity of the sensitive with the rational operations of the latter, lay at the heart of humanist thought. As long as the passions concerned bodily functions, their effects admitted description from the perspective of physiology and medicine. ${ }^{7}$ But this familiarity of body with mind, of the sensitive with the rational, was perceived, if not with anxiety, at least as an unsolved contradiction..$^{8}$ Descriptions of the workings of the passions were the effect of the belief in the humoural composition of the self: the passions originate in the middle part of our soul -the so-called sensitive soul- which is shared by men and animals, and which mediates between the vegetative soul -the one humans and animals have in common with plants- and the rational soul -owned by humans and angels alike. The imagination, a faculty of the sensitive soul, derives impressions of external objects from the senses, and summons up the presence of the purer spirits from the brain into the heart, which, influenced by the four bodily humours,

\footnotetext{
${ }^{6}$ Sir John Davies recounts it thus: "Euen so by tasting of that Fruite forbid, / Where they sought knowledge, they did error find, / Ill they desir'd, and ill they did; / And to giue Passion eyes, made Reason blind. / For then their minds did first in passion see, / Those wretched shapes of Miserie and Woe, / Of Nakednesse, of Shame, of Pouertie, / Which then their owne experience made the $[\mathrm{m}]$ know" $\left(1599: \mathrm{B}_{1}{ }^{\mathrm{r}}-\mathrm{B}_{2}{ }^{\mathrm{r}}\right)$. In Soellner's words, "self-knowledge had for Shakespeare and his audience a different emphasis from what it has for us. In most cases, the primary reference is to control of passion by means of reason" (1972:xiv).

${ }^{7}$ This issue is emphasised in recent work on literary representations of the passions. See the "Introduction" to Paster, Rowe, and Floyd-Wilson (2004), and also Paster (2004).

${ }^{8}$ As a conclusion to his learned discussion, Kocher provides an enlightening summary of this issue: "Being at a loss to know what to do with incomprehensible spirit, and finding it methodologically expendable in their study of the system of matter, many physicians acted as if it were not there. Psychologists, of course, were in much less danger of forgetting the soul, but they were unlucky victims of the great Elizabethan dualism. Of the two constituents of psychology, matter and spirit, one seemed to belong to the medical sciences, the other to ethics and religion. It is altogether fascinating to watch psychologists veering from one to the other, trying to hold together a topic which persisted in flying apart into halves separated by a metaphysical vacuum" (1953:305).
} 
pursues or eschews those very objects represented by our imagination. " "Blindnesse of vnderstanding" and "peruersion of will" were common effects of vehement passions, since the imagination was assumed to be responsible for representing to the understanding the good or evil of the objects it sought or avoided (Wright 1604:D8 ${ }^{r}$ ). In this sense, blaming the imagination and fantasy for interfering with the rational soul was a common attitude in Renaissance thought. ${ }^{10}$ The English physician Timothy Bright reminds us, for instance, in his Treatise on Melancholie (1586) that the imagination, under the effect of a surplus of melancholy humours, causes "fantasticall apparitions," whereas fantasy "compoundeth, and forgeth disguised shapes" (103).

But as long as the passions were conceived as perturbations originating in the inward soul, and thence as discontinuous with bodily matter, knowledge of them became a more problematic issue. Wright's insistence upon the passions' inaccessibility to our perception testifies to the problems involved. The fourth book of his treatise, devoted to explaining "how passions may be discovered," endeavoured, like Polonius, by indirections to find directions out, and hence advised methods of finding inward truths by observation of outward realities:

For that we cannot enter into a mans heart, and view the passions or inclinations which there reside and lie hidden; therefore, as Philosophers by effects find out causes, by properties essences, by riuers fountaines, by boughs and floures the kore and roots; euen so we must trace out passions and inclinations by some effects and externall operations; and these be no more than two, words \& deeds, speech and action: of which two, knowledge may be gathered from those affections we carry in our minds. $\left(\mathrm{H}_{5}{ }^{\mathrm{r}}\right)$

For Wright the "heart" and the "mind" were as central to passionate arousal as were their activities unattainable to external perception. Discovery of the passions needed to be pursued somehow obliquely. In Wright's description, obliqueness reveals a character which, from a semiotic point of view, may be called indexical and, from a rhetorical one, metonymic. Both concepts

\footnotetext{
${ }^{9}$ Most Renaissance psychological treatises account for this process in very similar terms. General accounts with many learned references can be found in Lily B. Campbell (1930:63-72), and Bamborough (1952:41-45).
}

${ }^{10}$ On derogatory views of the imagination, see Rossky (1958). 
comprise relations of contiguity and causality, as well as of presence and absence. As in our empirical observations of nature, Wright seems to suggest, we must arrive at the ultimate causes of human action through detection of external signs that are little else than effects of an elusive inward truth. As long as this becomes our basic mode of awareness, a universe of bodily fluids, organs and sensations dissolves into a referential network of speech and action whose nature is ultimately rhetorical. No wonder that since Aristotle rhetoricians had paid primary attention to the orator's ability to represent and to incite certain passionate states. ${ }^{11}$ At the level of speech, rhetorical inventio, dispositio, and elocutio shape representations of passionate processes, while they are themselves determined by the speaker's own emotions. At the level of deeds, rhetorical actio wraps the oratio in countenances, gestures, voices, intonation, and movements.

Among the various indices that guided the external observation of the passions, the face was a chief site of awareness. "Face" is a term whose early modern meanings range from "the front part of the head," the "visage," to more ample figurations of outward appearance. ${ }^{12}$ For Thomas Wright, "it cannot be doubted of, but that the passions of our mindes worke diuers effects in our faces," and for that very reason "wise men often, thorow the windowes of the face, behold the secrets of the heart:"

As the face of those which looke into waters shine vnto them, so the hearts of men are manifest to the wise [Prov. 27.18]: not that they can exactly, understand the hearts which be inscrutable, and only open unto God, but that by coniectures they may ayme well at them: for as he which beholdeth his face in the water, doth not discern it exactly but rather a shadowe, than a face; even so he that by external phisiognomy and operations will divine what

\footnotetext{
${ }^{11}$ The locus classicus for discussion of the passions in rhetoric is Book II of Aristotle's Rhetoric (1926:II.i.8). Quintilian's Institutio Oratoria provides a clearest formulation of this principle: "Quare in iis, quae esse verisimilia volemus, simus ipsi similes eorum qui vere patiuntur adfectibus, et a tali animo proficiscatur qualem facere iudicem volet" [Thus in those emotions, which we want to be verisimilar, we should be ourselves similar to those who verily suffer from those affections, and the speech should emerge from the same emotion as it intends to produce in the judge] (1921:2, VI.ii.27). I have followed this edition's Latin text but not the translation, which is my own.
}

${ }^{12}$ These are the main meanings of the word as defined in the OED (sense I and II). 
lieth hidden in the heart, may rather conceive an image of that affection that doth reign in the mind than a perfect and resolute knowledge [...]

And thus to conclude, we must confesse, that Passions haue certain effects in our faces, howbeit some doe shew them more evidently than others. Yet we may not say, that this face is the root \& core where the Passions reside, but only the rinde and leaues, which shew the nature and goodness of both the root and the core. $\left(\mathrm{C}^{\mathrm{r}}\right)$

Interpreting the face was then a form of insight or discernment, that is, the capacity of obtaining hidden truths from the examination of outward features and changing gestures. Yet Wright, a strongminded believer in this method, also informs us of its shortcomings: even the shrewdest examiner, Wright implies, must be content with conjectures that originate in external signs always at risk of misreading the self.

The examination of the face found its roots in the disciplines of physiognomy and rhetoric. The status of physiognomy as a science had fallen into discredit in the Renaissance. However, as Hardin Craig observed long ago, popular forms of knowledge in the English Renaissance frequently sought "short cuts to the absolute, back stairs approaches to certainty, get-rich methods of acquiring truth" (Craig 1927, qtd. in Camden 1941:400). The popularity of the pseudoAristotelian Physiognomonia during the Middle Ages was followed by the success of treatises like Giambattista della Porta's De Humana Physiognomonia or, in England, Thomas Hill's The Contemplation of Mankinde, or A Pleasant History Declaring the Whole Art of Physiognomy, whose various editions from 1571 to 1616 in the printing press of William Jaggard appear to have left a significant trace. ${ }^{13}$ Physiognomy, Hill admits, "instructeth a man by the outwarde notes, to foretell the naturall motions, and naturall conditions, that consist and dwell in many persons, especially in those, which live after their affection, and appetites, rather than gouerning themselues by reason" (1571:2 ${ }^{\mathrm{v}}$ ). Inward motions alter our outward appearance, and for that reason Hill fluctuates between the mechanistic interpretation of the static face and the awareness of accidental motions of the mind as inferred from changing gestures.

${ }^{13}$ On English Renaissance physiognomy and its precedents see Camden (1941), and Baumbach (2008:esp. 26-44). 
As he asserts, "in a man the face remayneth, but the countenaunce doth alter: so that the countinaunce is named of the Latine worde Volando, which properly in Englishe signifieth a flying, or vanisihing away" (1571:90 $\left.{ }^{r}\right)$. Hill produces physiognomic truth through bizarre linguistic operations: "face" and "countenance," two words frequently seen as interchangeable synonyms, are given differentiated meanings: human beings have unchanging faces but are capable of a multiplicity of meaningful gestures by setting their faces in motion, and thus the human "countenaunce" is as volatile as the Latin word which is adduced to be its etymological source. ${ }^{14}$

Physiognomic wisdom endured in part for its connection with the art of rhetoric. The influence of Ciceronian oratory was crucial in this sense. Cicero's detailed account of delivery or actio in De Oratore devoted a whole chapter to the role of gestus in the expression of motus or passions. In Cicero's words, "animi est enim omnis actio, et imago animi vultus, indices oculi; nam haec est una pars corporis quae quot animi motus sunt tot significationes et commutationes possit efficere" ["delivery's main concern is with the emotions, and the passions are mirrored in the face and expressed by the eyes; for this is the only part of the body that can produce as many meanings and variations as there are passions of the mind"] (Cicero 1942:III.lix.221; my translation). Unlike in physiognomy, whose main object was the static face or facies, the rhetorician's concern with vultus addresses the self-conscious ability to produce modulations and variations. ${ }^{15}$ The orator's face is not merely a passive mirror to

\footnotetext{
${ }^{14}$ Hill's etymological deductions are surprising. To find connotations of flying and changeability in a word whose form and meaning were commonly merged with those of "continuance" and "continence," and therefore, with ideas of contention and stability, is amusing enough. The Latin terms facies and vultus, and Italian faccia and volto, are pairs matching "face" and "countenance": the first undoubtedly provides the etymological origin of "face"; we might search in the second and its Englishing "vult" -for which the OED registers usage between 1375 and 1610- and find a not very outrageous phonetic closeness to Latin volare. John Florio's Italian-English dictionary A World of Words (1598) points at the homonymy of volto in Italian, meaning "a face, a looke, a countenance, a visage, a fauour or cheere of man," but also signifying, as an alternative conjugation of the past participle volgiuto, of vólgere, "turned, overturned, tossed, $\mathrm{t}[\mathrm{r}] \mathrm{ubled}$, transformed, revolted, changed, inclined, bent [...] revolted to and fro" (455), a word which in English gives "vault", meaning "leap", "jump high", "rise", "surmount", as in Shakespeare's "vaulting ambition, which o'er-leaps itself" (Macbeth 1.7.27). All references to this play are from Braunmuller's edition (1997).

${ }^{15}$ The grammarian Nonius Marcellus differentiates these terms by stating that "vultus est voluntas quae pro moto animi is facie ostenditur" [the countenace is our will as it
} 
the mind, and hence the importance of practical rhetoric in the training of Elizabethan players in the arts of feigning. ${ }^{16}$

So far we have seen two paths by which the Renaissance explored the nature of human passions: one addresses the phenomenon, and its subjects are inward motions, disturbed minds, troubled souls, and altered bodily organs and fluids; the second involves its access through signs and indices, and its subjects are words, deeds, and faces. The crossroads is the insistence upon external observation as a necessary, though faulty and incomplete, aid to human insight. In its self-assumed role as imago mundi the theatre became a privileged vehicle for the exploration of the relationships between inward and outward nature, between external movements and inner motions, between seeming and being. Shakespeare and his contemporaries show a concern with the gaps and fissures on the paths that led from indices to their alleged truths. The Shakespearean poetics of the passions addresses not the denial of the inward self, but the paradoxical and incomplete nature of our modes of awareness and insight into its nature. In this Shakespeare's thought was an effect of humanist ideas. Vives, for instance, had concluded in De anima et vita (1538) that "it is not a matter that should be too important for us to know what the soul is, but rather [...] what it is like and what its operations are." ${ }^{\prime 17}$ But Shakespeare's

is shown in the face through the passions of our mind] (2003:III.689). St. Isidore of Seville also explains the difference in his Etymologies: "Facies dicta ab effigie. Ibi est enim tota figura hominis et uniuscuisque personae cognitio. Vultus vero dictus, eo quod per eum animi voluntas ostenditur. Secundum voluntatem enim in varios motus mutatur, unde et differunt sibi utraque. Nam facies simpliciter accipitur de uniuscuisque naturali aspectu; vultus autem animorum qualitatem significat" [Facies is named after the effigy. In it the entire figure of man is shown indeed, as well as knowledge of each person. It is also called vultus, because through it the will (voluntas) of the spirit is shown. In accordance with one's wishes the face changes into various motions, and thence a difference between these terms is found: facies refers to the natural appearance of each person; vultus for its part signifies a state of mind] (1982:II, XI.1.33-34; my translation). Unlike Hill, Isidore made vultus derive from volere (i.e., to wish) and not from volare (i.e., to fly).

${ }^{16}$ On the rhetorical training of Elizabethan actors see Joseph (1951:esp. 60-82), and Thomson (1997).

17 "Anima quid sit, nihil interest nostra scire, qualis autem, et quae eius opera, permultum" (1782:I.xii.332) This idea is emphasized by Marcia L. Colish in her study of Vives' psychology. As she states: “This distinction drawn by Vives between man's essence and his activity springs from his conception of man's intellectual limitations. The essences of things may be objects of wonder; they are not, however, legitimate 
knowledge also unveils its own poetic and theatrical nature: as long as they are arts of feigning, poetry and the theatre find common ground in the art of the rhetorician. Like rhetoric, drama grants to speech and action the value of contrived artifice. But even beyond the orator's, the poet's, and the dramatist's art, gestures and words are the central indices to everyday concerns with show and tell, concealment and silence, betraying and revealing, discovery and misinterpretation. In the act of bearing themselves in the world, of showing or concealing their aims from others, individuals deal with words and action in rather histrionic ways. Shakespeare understood drama as a rhetorically enhanced form of these concerns: the theatre displays the arts of feigning, imitation and counterfeit in order to emphasize the many fissures found in processes of self-awareness. The focus on Macbeth here is justified by the play's obsessive examination of the relationship between outward and inward realities: ${ }^{18}$ in Macbeth Shakespeare engages in an unflinching search for the inward soul, understood as an organic, controlling and primarily non-material entity - what the play's hero calls "my single state of man" (1.3.141). The play seems to declare, quite paradoxically but with genuine scepticism, that the impossibility of knowing the inward self properly and completely is one condition of its existence. In his investigation of the passions of the mind, Shakespeare understands the theatre as the art of suggesting that there is always more to know about the inward self, though no accurate ways of knowing it. $^{19}$

objects of knowledge. Although Vives as well as Pico is concerned with selfknowledge and repeatedly enjoins to seek it, he does not think that a grasp of the essence of the soul falls within its scope. The intrinsic nature of the soul remains hidden from man [...] God has not granted us the faculties of intelligence, will, and memory so that we may know what they are [...] When Vives does at length analyze the nature of the soul, he proceeds not by definition but by description, in terms of its functions and aptitudes" (Colish 1962:11).

${ }^{18}$ For the import of vision and the visual in the play see Diehl, for whom Macbeth "examines the act of seeing and interpreting an uncertain visible world. This uncertainty, and the epistemological questions it raises, sustain the play dramatically and motivate the action" (1983:191).

${ }^{19}$ For other accounts of Macbeth in terms of the passions of the mind, see Campbell (208-239), whose account of the play as "a study in fear" continues to be useful. See also Kirsch (1972:76-103). The classic psychoanalytical view is Freud's 1916 essay (1977:151-175). See in this respect Kerrigan (1996). 


\section{The mind's construction in the face}

In the first act of Macbeth a distressed Duncan complains about the Thane of Cawdor's treachery in terms that betray a thorough disavowal of physiognomy: "There's no art / To find the mind's construction in the face; / He was a gentleman on whom I built / An absolute trust" (1.4.11-14). We should note that the face that has deceived Duncan is one that the audience will not see, since neither Cawdor's participation in the wars nor his execution are scenes of the play. Cawdor is a name but not a character, and thus the king's words may easily divert our attention outside the play's action -we thus judge them on the basis of an alleged long acquaintance of the king with his thane. Duncan expresses his inability to have read his man of trust's true meaning in the past, as well as his present disappointment -hence his words advance his later failure to interpret Macbeth's mind. ${ }^{20}$ Yet this reading ignores the fact that the Thane of Cawdor does gain, at least indirectly, some sort of physical and psychological presence in the play through Malcolm's words, which narrate Cawdor's death by execution in an act of rhetorical enargeia. ${ }^{21}$ Malcolm has not seen Cawdor's death, but has spoken "with one that saw him die" (1.4.4). In Malcolm's second-hand version of the eye-witness's reporter, Cawdor "very frankly confessed his treasons," and "set forth / A deep repentance" (1.4.5-7; my emphasis). A paradox should be noticed here: the inner depth of Cawdor's repentance -Shakespeare's phrasing hints at the idea of the sinner turning deep inward for self-examination- is "set forth,"

${ }^{20}$ Holinshed must have provided Shakespeare with information on Duncan's weakness. He states that "Duncane was soft and gentle of nature," and adds: "the beginning of Duncan's reign was very quiet peaceable, without anie notable trouble; but after it was perceived how negligent he was in punishing offenders, manie misruled persons tooke occasion thereof to trouble the peace and quiet state of the common-wealth, by seditious commotions which first had their beginnings in this wise" (1586:II, fol. 168/2/24-25, 33-39).

${ }^{21}$ A locus classicus for the definition of enargeia is Quintilian's Institutio Oratoria: "Insequitur enargeia, quae a Cicerone illustratio et evidentia nominatur, quae non tam dicere videtur quam ostendere; et adfectus non aliter, quam sirebus ipsis intersimus, sequentur" ["This is followed by enargeia, which in Cicero is called illustratio and evidentia, which seems not so much to narrate as to exhibit; and affections will be presented no less than if we witnessed the very same things"] (1921:2,VI.ii.32; my translation). English Renaissance accounts of enargeia were based on these classical definitions as well as Erasmus's De duplici copia verborum ac rerum (1521). A useful summary is Doran (1954:242-244). 
that is, laid out, produced outwardly, delivered by means of words, gestures and faces. Malcolm's words leave us with the doubt whether Cawdor's outward show is a window to a true repentant soul, or whether this "deep repentance" constitutes a theatrical display, a hypocritical gesture concealing behind the facade of sincere remorse a treacherous inward nature. Cawdor's delivery of his "deep repentance" is the object of Malcolm's tale:

[...] Nothing in his life

Became him like the leaving it. He died

As one that had been studied in his death,

To throw away the dearest thing he owed

As 'twere a careless trifle. (1.4.7-11; my emphasis)

What others have seen, what Malcolm narrates, and what we must content ourselves with listening to and representing to our imaginations, is Cawdor's success in exhibiting his death as the perfect epitome of Stoic fortitude and temperance. At the moment of his execution, Cawdor proves to be a master of becoming, that is, of decorum. Earlier in the play, Duncan has resolved not to let his inward will be seduced by Cawdor's outward nature again: "No more that Thane of Cawdor shall deceive / Our bosom interest" (1.2.62-63; my emphasis). But now one wonders to what extent Cawdor has, in rehearsing his submissive downfall, taken in Duncan's will again.

As we have to decide on Cawdor's soul, the Renaissance logic of outward versus inward nature may perhaps assist us: Cawdor is a traitor and a hypocrite, and hence a good rhetorician and an actor who has managed to print repentance on his histrionic gestus in order to hide his treacherous meaning. But we may choose a different interpretative path -one that makes Cawdor a much more elusive figure: why can a man that has betrayed his king not be a true model of temperance at the moment of death? Just because these two traits do not sit well together in the often Manichean moral codes of Renaissance tragedy? Cawdor's countenance as described by Malcolm may not be a false but rather true index to a complex, unreachable and enigmatic mind. Duncan's absolute trust or distrust of physiognomy is thus rendered irrelevant by Shakespeare even in its very pronouncement, and we are invited to pursue a different logic: as our ways of access to the inward self are conjectural and subjective -and this we know through Thomas Wright-, so our 
conclusions must be fragmentary and flawed. Seen in this light, Duncan's allegorical role as a foolish prince that cannot construe his subjects' minds reveals him as a model for other characters', as well as the audience's, interpretative shortcomings. And what of Cawdor? He certainly suggests as much about the inscrutability of the inward self as about the intricacies of the early modern art of playing. ${ }^{22}$

Far from overstating the importance of this moment, my reading of Cawdor's behaviour and Duncan's disappointment means to address the play's obsession with the relations between gestural and interior dimensions of the self. As Banquo meets the Wëird Sisters he wonders whether their looks match what they are: "Are ye fantastical, or that indeed / Which outwardly ye show?" (1.3.51-52). And he dares to interpret their minds by dint of their gestures: "You seem to understand me, / By each at once her choppy finger laying / Upon her skinny lips" (1.3.41-43). Later, as Macbeth is first possessed with the temptation to murder Duncan, he exclaims: "Stars hide your fires, / Let not light see my black and deep desires" (1.4.51-52). Macbeth either means that light can penetrate his body and see his passions deep inside, or he actually wishes darkness could mask a face that mirrors the evil of his inward soul. If Macbeth's obsession is with being observed -with his own face betraying his intentions to others-, Lady Macbeth sees herself on the other side as an expert physiognomist. ${ }^{23}$ As she first meets him in Dunsinane, she thinks herself entitled to interpret, borrowing Wright's words, Macbeth's "silent speech pronounced in the very countenance:"

Your face, my Thane, is a book where men

May read strange matters; to beguile the time,

Look like the time, bear welcome in your eye,

Your hand, your tongue -look like th'innocent flower,

But be the serpent under't $[\ldots]$

Only look up clear

To alter favour, ever is to fear. (1.5.6o-71)

\footnotetext{
${ }^{22}$ My reading of this scene challenges Barker's idea of interiority as a merely theatrical, rhetorical, or "gestural" pose (1984:esp. 35-37).

${ }^{23}$ This point has been made recently by Baumbach (2008:128-130).
} 
Lady Macbeth's proficiency as an observer and as a practical advisor is reinforced by the exemplary wisdom behind her words. On the one hand, Geffrey Whitney's emblem 24 in his A Choice of Emblemes (1586) appears as a possible source to her advice, even if Whitney's motto -Latet anguis in herba, [a serpent lies hidden underneath the grass]- and epigram are certainly intended for the sake of virtuous example and not of Machiavellian counsel. ${ }^{24}$ On the other hand, the conceit of a face as a book whose outward marks reveal the innermost essence of a human being is consistent with Renaissance notions of character. Viola's remark to the Sea Captain at the beginning of Twelfth Night provides an interesting instance: "I will believe thou hast a mind that suits / With this thy fair and outward character" (1.2.46-47). ${ }^{25}$ Peter Thomson has reminded us of the perils of misreading "outward character" as an oxymoron, if we understand character merely in the present-day sense of "a property of the psyche." Conversely, Thomson continues, early modern meanings of the word point to "the formation of letters in writing and printing" (1997:321). We should implement Thomson's remark by saying that it is the meaning of character as an outward imprint susceptible of being read -or misread- that determines the Renaissance ideal of an inward signified that can be accessed through signifiers made of outward traits and faces: for lady Macbeth and Viola, Macbeth's "book" and the Captain's "character" are meaningful only as long as they are external realities pointing inwards. But characters and books are sources of knowledge as well as agents of deceit, of good and bad writing, of reading and misreading. In this sense, Lady Macbeth's advice to her husband could perhaps be read in relation to Edward Knowell's recommendations to his cousin, the country gull Stephen, in Jonson's Every Man in His Humour:

\footnotetext{
${ }^{24}$ The first stanza of Whitney's subscriptio addresses the very outward/inward dualisms that with which essay is concerned: "Of flattringe speech, with sugred words beware, / Suspect the harte, whose face doth fawne, and smile, / With trusting these, the worlde is clogg's with care, / And fewe there are can scape these vipers vile: / With pleasing speech they promise, and protest, / When hatefull hartes lie hidd within their brest" (Whitney 1586, in Daly 1998:113).

${ }^{25}$ Another is certainly Sir Philip Sidney's sonnet 71 in Astrophel and Stella: "Who will in fairest booke of Nature know [...]" Sidney's conceited logic leads to the macrocosmic "booke of Nature" to the microcosmos of Stella's "beautie," whose outward show points to inner "virtue:" "That inward sunne in thine eyes shineth so" (Sidney 1931:74).
} 
Come, wrong not the quality of your desert, with looking downward, coz; but hold up your head, so; and let the Idea of what you are, be portrayed i' your face, that men may read i' your physnomy, "Here, within this place, is to be seen the true, rare, and accomplished monster, or miracle of nature," which is all one. (1.3.107-113)

Stephen is tricked into believing that outward arrogance will amend his inward self. Knowell's words fashion the face as a readable motto of inner worth. In the satirical logic of urban comedy, the "true, rare, and accomplished monster" easily reveals Stephen as a false, ordinary, and ridiculous freak. Saving differences in context, genre, and intention, the Jonsonian tag becomes emblematic of what Lady Macbeth attempts to make of her husband. Following her guidance, Macbeth nourishes the fantasy that his outward looks will tell something other than he is: "Away, and mock the time with fairest show, / False face must hide what the false heart doth know" (1.7.82-83).

However, Macbeth's belief in self-control is permanently contrasted with the play's continual focus on his loss of temper, as made clear from the very first encounter with the Wëird Sisters:

\section{[...] Present fears}

Are less than horrible imaginings:

My thought, whose murder yet is but fantastical,

Shakes so my single state of man, that function

Is smothered in surmise, and nothing is

But what is not. (1.3.138-143)

Macbeth's loss of temper, as caused by the thoughts spurring his mixed passions of fear and desire, "shakes" the imagined unity of an undivided mind, whose organic, controlling "function" collapses under the urge of strong imaginations. In this, Shakespeare might seem to tell us, the new Thane of Cawdor lacks the strength of soul shown by his mysterious predecessor.

Macbeth's raptures are a frequent focus of attention. Early on, Banquo notices the protagonist's distemper after listening to the Weïrd Sisters' prophecy: "My noble partner / You greet with present grace and great prediction / Of noble having and of royal hope / That he seems rapt withal" (1.3.52-55; my emphasis). Even if we may not doubt the visual evidence of Macbeth's rapture, whose signs should be shown in performance and whose causes we attribute to 
the impression made by the witches, Banquo presents it as a matter of seeming, that is, of outward show hinting at inward passion. Later in the same scene, after Ross and Angus proclaim Macbeth Thane of Cawdor, he insists on his earlier suppositions: "Look how our partner's rapt" (1.3.140). These are Banquo's words after Macbeth's first long aside: "Two truths are told, / As happy prologues to the swelling act / Of the imperial theme" (1.3.126-128). But awareness of Macbeth's state of mind, even when it appears as unquestionable to us, is for Banquo little else than an impression derived from faces and gestures. Awareness is not necessarily followed by certainty. Using the above-quoted words by Machiavelli, Banquo sees what Macbeth seems but we wonder whether he perceives what he feels, thinks and is. Neither would we if our only path to Macbeth's inward self were our perception of his looks as guided by Banquo. No matter how revealing Macbeth's face is, our closest knowledge of his "true" passions comes from Shakespeare's exercise in rhetorical pathopoeia, presented in the form of an aside: ${ }^{26}$

This supernatural soliciting

Cannot be ill, cannot be good. If ill,

Why hath it given me earnest of success,

Commencing in a truth? I am Thane of Cawdor.

If good, why do I yield to that suggestion

Whose horrid image doth unfix my hair

And make my seated heart knock at my ribs

Against the use of nature? Present fears

Are less than horrible imaginings. (1.3.129-137)

J. B. Bamborough has drawn attention to the importance of socalled "mixed" and "conflicting passions" in Renaissance tragedy (1952:43). Macbeth's words express such a mixture through the conflict between the concupiscible passion of Fear and the irascible passion of Hope, thus showing the mind's split concern for what is to come. ${ }^{27}$ Besides, his account of the workings of these perturbations within his inner self roughly matches the phenomenological description provided above: an external event -the sisters' "supernatural soliciting"- acts as the provoking agent of his passions

\footnotetext{
${ }^{26}$ The Renaissance rhetorician Richard Sherry informs us that pathopoeia takes place when "feare, anger, madnes, hatered, envye, and lyke perturbations of mynde is shewed and described" (1550:Eii). A useful account of the uses of pathopoeia in Renaissance tragedy is McDonald (1966).
}

${ }^{27}$ On traditional classifications of the passions see Bamborough (1952:43-44). 
and suggests itself to the imagination, which, in summoning the spirits and humours to the heart, produces strong bodily impressions. However, the corporeal and mental materiality of this process would be of little value without the text's rhetorical materiality. In this sense, conflicting passions let themselves be shown here by means of rhetorical diuisio or dilemma, which, according to Henry Peacham, occurs "when we divyde a thing into two partes, and reprove them both by shewing reasons" (1577: $\mathrm{T}^{\mathrm{r}}{ }^{\mathrm{r}}$. Macbeth's alternate reproofs of "ill" -the reason for his fear- and "good" -on which his hope is grounded- constitute the most accurate indices to a divided inner mind's disturbance.

Disparity between Banquo's and the audience's forms of access to Macbeth's passions reveals a consistent focus on the difference between the value of gesture and the power of words. Like Duncan, Shakespeare's characters pursue the mind's construction in the face. But the face is a lame index in need of the supplement of words, a dimension reserved for the audience's ears only. The complex game of criss-crossed impressions and reactions to Macbeth's new rapture in the banquet scene is perhaps the best instance of Shakespeare's method. Unlike Macbeth, neither the thanes nor the Queen can see the ghost of Banquo. Like an aside or a soliloquy, the ghost reveals that a full perception of the hero's passions is a matter between the Scottish king and the audience only. However, it is Lady Macbeth that first emerges as mediator between Macbeth and his beholders:

Sit, worthy friends, my lord is often thus.

And hath been from his youth. Pray you keep seat,

The fit is momentary, upon a thought

He will again be well. If much you note him

You shall offend him and extend his passion;

Feed, and regard him not. (3.4.53-58)

Lady Macbeth's awareness points to her husband's outward "fit," taken here as an unmistakeable index to his inward "passion." But her main concern is the degree of the thanes' awareness, and what she can do in order to diminish its scope. Her words intend to produce a misleading gloss of what she mistakenly thinks her husband's passion is, since she fears that her husband's true inner self will become the more conspicuous the longer the thanes "note" and "regard" him. Both verbs betray the pre-eminence of sight in the process of detecting the passions. Lady Macbeth and the thanes rely 
on what they see; conversely, we access Lady Macbeth's fear through what she says:

(aside to Macbeth) O proper stuff!

This is the very painting of your fear,

This is the air-drawn dagger which you said

Led you to Duncan. O these flaws and starts,

Impostors to true fear, would well become

A woman's story at a winter's fire,

Authorized by her grandam -shame itself,

Why do you make such faces? When all's done

You look but on a stool. (3.4.60-68)

At stake in both speeches is the difference between what Macbeth sees -the ghost of Banquo sitting on Macbeth's throne- and what the others see -"a stool." "The very painting of your fear" explains quite accurately the workings of the passions as understood by Renaissance psychology and explained above. "Fear" takes place in the realm of the active imagination, being a secondary derivation of a primary perception of objects through the senses. To see what is not there as an effect of a fit of passion is indeed the imagination's false "painting" under the influence of a vehement perturbation. But to Lady Macbeth the problem is not only what Macbeth can see but also what the thanes could see if they read Macbeth's countenance properly. The King's "fit," his "flaws and starts," and above all, his "faces" may reveal his true self to them. Whereas for Lady Macbeth the king's visions are false "paintings" of his fantasy, his looks and gestures may become true mirrors to his soul. The presence of the supernatural in Macbeth serves here only to remind the audience of the insurmountable gap between being and our awareness of it. The source of Lady Macbeth's unease -her naming "impostors to true fears" those gestures which may become the true harbingers of Macbeth's passions- is her husband's face-making, namely his changing countenance or vultus.

The impressions of a privileged Jacobean playgoer in Shakespeare's time testify to the validity of Wright's description of the process of detection. Dr. Simon Forman in his Booke of Plaies (1611) registers thus his remembrance of the banquet scene from a 1611 performance at the Globe:

The next night, beinge at supper with his noble men whom he had bid to feaste to the which also Banco should have com, he began to speake of Noble banco, and to wish that he wer ther. 
And as he thus did, standing up to drincke a Carouse to him, the ghoste of Banco came and sate down in his cheier behind him. And he turninge About to sit downe Again sawe the goste of Banco, which [af]fronted him so, that he fell into a great passion of fear and fury, Utterynge many wordes about his murder, by which, when they [he]ard that Banco was Murdred they Suspected Mackbet. ${ }^{28}$

Forman names Macbeth's conflicting passions of "fear" and "fury," these being products of an impression upon his sense of sight. ${ }^{29}$ Yet he introduces the new element of the "many wordes about his murder" by which the thanes "Suspected Mackbet." Forman shifts the focus of attention from deeds and faces to words. Macbeth does, as a matter of fact, utter many words about Banquo's murder in this scene, but none which, at least overtly, reveals the deed or Macbeth's responsibility for it, and certainly none which raises the thanes' overt suspicions within the bounds of this scene -it is not until two scenes later that Lennox voices them: "My former speeches have but hit your thoughts / Which may interpret further," he communicates to an unnamed Scottish Lord (3.6.1-2). Forman's memory may be over-reading or misreading the scene when attributing the thanes' suspicions to Macbeth's words -my statement is valid as long as it speculates on a performance whose gesturing does not overdo the plays' script as we know it-, but this interpretative excess is perhaps emblematic of different processes operating in our interpretations of dramatic texts and theatrical scenes: first, Forman synesthetically attributes to the effects of words what we have actually seen and vice versa; second, he attributes to the thanes' reactions as characters in the play what is actually his own reaction as spectator of it, thus misconstruing the differences between their knowledge and his knowledge of Macbeth's secrets. A magma of words, gestures and actions on the one hand, and a bundle of readings, impressions and perceptions, on the other,

\footnotetext{
${ }^{28}$ Simon Forman, Booke of Plaies (Bodleian Library MS. Ashmole 208, fols. 207 ${ }^{\mathrm{r}-\mathrm{v}}$ ), quoted in Braunmuller, ed. (1997:58). On early Globe performances and Forman's account, see Bartholomeusz: "The reactions observed, fear, the impulse to retreat, and fury, the impulse to attack, indicate that the Elizabethan actor was bringing complex feelings to the surface" (1969:8).

${ }^{29}$ Macbeth's description of his own face must have also aided to form Forman's impression: "When now I think you can behold such sights / And keep the natural ruby of your cheeks, / When mine is blanched with fear" (3.4.115-117).
} 
constitute the stuff that make up a soul, or better, what we can aspire to know of it. And here lies perhaps the ultimate meaning of Duncan's "mind's construction," whose counterpart is not so much the "face" as it is the "mind" itself. In addressing the difference between the mind and the mind's construction -not only what the mind is made of but also and primarily what we can construe or make of it- Shakespeare, like Vives, acknowledges that, confronted by the inscrutability of its ultimate essence, man should proceed to an understanding of the self through the incomplete aid of indices and functions.

\section{The Divine, the Physician and the Critic: Minds, Bodies, Texts}

"Observe Also how Mackbetes quen did Rise in the night in her slepe, \& walke and talked and confessed all, \& the docter noted her wordes" (Forman, in Braunmuller 1997:58). Forman's memories of the play's performance raise a few questions if we rely on the only authoritative extant text of Macbeth. The fifth act opens with the Scottish Queen walking in her sleep under the attentive scrutiny of her maidservant and a doctor:

DOCTOR You see her eyes are open.

GENTLEWOMAN Ay but their sense are shut.

DOCTOR What is it she does now? Look how she rubs her hands.

GENTLEWOMAN It is an accustomed action with her, to seem thus washing her hands: I have known her continue in this a quarter of an hour. (5.1.23-26)

In keeping with the play's logic, the Queen's looks and gestures remain to her observers' eyes imperfect keys to her inner mystery. Such imperfection lies in the obliqueness of Lady Macbeth's action, whose continuous hand-rubbing metonymically replaces handwashing, a gesture which points literally to the concealment of proof -Macbeth's bloody hands in the second act- and implies symbolically the desire to purge the soul of murderous guilt: "this my hand will rather / The multitudinous seas incarnadine, / Making the green one red" (2.2.263-265). The Queen's wide-open eyes are perhaps a more complex issue: what the observers perceive here is a disentanglement of the organ -"eyes"- from its function "sense"- as materialized in the displacement from literal -"open"- to 
metaphorical -"shut." But the text may not restrict its focus to moral collapse through the psychological gap opened in the self between the functions of a controlling organism and its rebellious organs. The scene also points to another gap between self and other, materialized in the observer's attempt to gain true access to the interstices of someone else's inner self. We may be less prone to read "sense" as the truth of the Queen's soul, which is hinted at, though not fully explained, by her wide-open eyes. The eyes' "sense" is also "shut" to the observers' understanding. We are thus put on two different tracks: on the one hand, the failures of self-awareness understood as knowledge of one's own affects and intents; on the other, the inability to interpret signs as indices to others' inner selves. ${ }^{30}$

However, as Lady Macbeth speaks, her partial revelations of murder start to round off the "sense" advanced by her indexical gestures. The Doctor's reaction reveals him to be a shrewder psychologist than a physician: "Hark, she speaks, I will set down what comes from her, to satisfy my remembrance the more strongly" (5.1.38-29). The movement is not only from gesture to word: "besides her walking and other actual performances, what at any time have you heard her say?" (5.1.10-11). It also concerns a rendition of oral into written language -i.e. "set down"- as firmer ground for further interpretation. "Remembrance" of "actual performances" through writing will be certainly stronger than mere recollections of impressions derived from words and gestures - a procedure that should not surprise any Shakespeare critic.

The Doctor's conclusions, albeit refusing to reveal any explicit "sense," seem to leave no doubt: "infected minds / To their deaf pillows will discharge their secrets. / More she needs the divine than the physician" (5.1.62-64). In the context of early modern psychology, the soul's disturbance could be the effect of a literal, i.e. physical, "infection" of the brain or any other organ, as attested by the belief in the workings of the four bodily humours, and more

\footnotetext{
$3^{30}$ This may also apply to Macbeth's words to the Ghost of Banquo: "Thou hast no speculation in those eyes / Which thou dost glare with" (3.4.95-96). Speculation is certainly vision or sight, or even as the Oxford editor Nicholas Brooke suggests, "comprehending vision" (1990:158n). But the Ghost's lack of vision seems to suggest Macbeth's faulty "speculation," that is, his own inability to infer meaningfulness from the Ghost's face.
} 
specifically, in the effects of melancholia. ${ }^{31}$ But the Doctor's words cancel out that explanation in Lady Macbeth's case. Even his later diagnosis of "thick-coming fancies / That keep her from her rest" (5.3.39-40) conceives the thickness of the Lady's mind more as a metaphor than as any real pollution of the Lady's brains. The Doctor's phrasing of the Queen's malaise certainly seems to countervail her own invocation earlier in the play of the physical materiality of "spirits" that can "make thick" her "blood" and "stop th'access and passage to remorse" (1.5.38,40,41). Macbeth's own words to the Doctor are a desperate cry for a physiological answer to the riddle of his wife's obscure passions:

[...] Cure her of that.

Canst thou not minister to a mind diseased,

Pluck from the memory of a rooted sorrow,

Raze out the written troubles of the brain,

And with some sweet oblivious antidote

Cleanse the stuffed bosom of that perilous stuff

Which weighs upon the heart? (5.3.40-46)

Macbeth's insistence is on physical matter: that is, on the "stuff" whose weight clots his wife's "heart" and "stuffed bosom," and on the "antidote" that will rinse out her heavy infection. Even a "rooted" passion could be, in the King's act of wishful thinking, materially "plucked" from the "brain," as if sorrow were made of "written" traces conferring a tangible existence upon the Lady's corporeal memory. Macbeth wishes there were written marks on the surface of our organs showing our passions. Against this stubborn adherence to matter, the Doctor believes in writing only as a meaningful but imperfect sign system to aid his memory from his ready pocket notebook. His final verdict is also corrective of Macbeth's materialist expediency: "Therein the patient / Must minister to himself" (5.3.46-47; my emphasis). The adverb makes clear the inwardness of Lady Macbeth's secret "sense." Whatever the essence of the self-administered remedy recommended by the

\footnotetext{
${ }^{31}$ Bright's description of unnatural melancholy rising up to the brain by "adustion" or excessive heat is just one instance of a commonplace in early modern treatises: "For becomming more subtile by heate, both in substance, \& spirit, it passeth more deeply into all the parts of the instrument it selfe, and is a conueyance also to the humour of the same kind: making away for naturall melancholie, wherewith it is mixed, into the verie inward secrets of those instruments, whose passions are affected, euen heart and braine" (1586:111).
} 
Doctor, its intellectual or spiritual nature is in stark contrast with the very materiality of the "sweet oblivious antidote" desired by Macbeth. And yet the Doctor cannot look "therein:" he can simply surmise inward "sense" from the outward show of the Lady's gestures and words. As we compare the Doctor's sentence with Hamlet's "that within that passeth show" -which, in spite of very recent readings, continues to be paradigmatic of Shakespeare's focus on a hardly accessible human inwardness- we can conclude that, from the perspective of a qualified other, Lady Macbeth's "that within" will out only partially and with the aid of qualified interpreters of her "performances." ${ }^{2}$

The Doctor scenes in Macbeth might suggest different levels of looking into the play's "stuff." The first remains within the realm of character. Macbeth's figuration of the stuff inside his wife's body looks like a refusal to see the true "sense" in her soul. When earlier in the play Lady Macbeth qualifies ironically her husband's hallucinatory visions of the "air-drawn dagger" and the ghost of Banquo as "proper stuff," the effect might be quite similar, since the phrase suggests her complaint at Macbeth's refusal to deal with the materiality of the world around him -the dinner, his guests, his newly acquired throne and crown- and his surrender to immaterial visions: "this is the very painting of your fear" $(3.4 .62,60,61) .{ }^{33} \mathrm{In}$ both moments of the play the audience will perceive something wrong (here intended in a logical sense only) in the materialism invoked by both King and Queen. On the other hand, the Doctor redirects our considerations of matter to a more figurative sense. These relations linking matter and spirit, body and soul, will allow us to use the former as partially reliable guides to the latter, since, and despite the Renaissance belief in their contiguity, the inner self was seen as elusive of physical substance.

At a different level, the "stuff" in Macbeth becomes paradigmatic of two forms of critical understanding of Shakespeare's representation of the passions. Recent approaches to early modern literature's treatment of emotion have resorted to labels such as "cultural history" or "historical phenomenology" to stress the

\footnotetext{
${ }^{32}$ See in this sense footnote 2 above for contending readings of this line in Hamlet.

${ }^{33}$ Crawford points to the other uses of "stuff," especially in the tragedies and late romances, "in a subjective sense, for the things of the mind or spirit" (1915:159).
} 
importance of pre-Cartesian theories of the humoural body in cultural figurations of human affections. In words of Gail Kern Paster that specifically address Shakespeare's plays, "dramatic narratives of passion take place in an imagined physical and physiological environment epistemically prior to postEnlightenment dualism" (Paster 2004:244). ${ }^{34}$ I take Paster's work as representative of a decidedly radical challenge to interpretations of the early modern subject in terms of dualisms of body and soul. Against alleged post-Cartesian habits of imagining separate realms for passion and reason, body and soul, psychic and physiological processes and states, Paster's study means to redirect our looks to "the overarching unity of physical and psychological in early modern behavioral theory" (2004:76). Her aim is to restore our abilities to read early modern representations of the passions in their embodied materiality, and to encourage an interpretation of the early modern expression of the passions that will shun the risk of reading "abstraction and bodily metaphor" where "materiality and literal reference" to the body are meant (2004:26). In stark contrast, earlier studies on the Renaissance passions, while acknowledging the importance of the physiological basis of Renaissance psychology, are equally emphatic as to the early modern understanding of a dual nature of humankind whose invention is far from being as late as Descartes. Paul H. Kocher, a representative of a line of research into the cultural history of the Renaissance that some associate with "old historicism," calls the psychological dyad of body and soul "the great Elizabethan dualism" (1953:305), and traces the often contradictory accounts, divided between ascribing cause, effects, and processes to body and soul, of the passions and psychological ailments as found in Renaissance writers. His work serves here as instance of a prolific but unfairly neglected critical school. ${ }^{35}$

Kocher sees the psychological interest in the passions as trapped within the irreconcilable quarrels between medical science and religion. For the Renaissance psychologist "the question was not so much the human relationship to God as what man was in himself,

\footnotetext{
${ }^{34}$ Another study following a similar line of thought is Schoenfeldt, who nevertheless acknowledges that the early modern focus on physiology can be explained by its discursive ability "to render inwardness tangible" (1999:38).

${ }^{35}$ Campbell (1930), Craig (1952), Bamborough (1952), and Soellner (1972), are perhaps the most relevant examples for the purposes of this paper.
} 
what were the parts or faculties of his inner mechanism, how he thought, felt, remembered, willed, and whether these processes moved freely or were impeded by some malady" (Kocher 1953:306). For that reason, "the basic need of psychologists was to see the human being as an order functioning steadily and understandably. To them man must be an organism which, though partly inside (as body) and partly outside (as soul) the system of strictly natural laws, yet worked by principles of its own and was at least not supernatural" (Kocher 1953:313). The psychologist for his part lent the theologian the "whole concept of what the several faculties of the soul were and how they synchronized in the organism" (319).

Kocher's thesis was implemented by his later paper on the Doctor scenes in Macbeth published in the 1950s, some of whose points I have made mine in the above paragraphs. In Kocher's argument, it is the Doctor himself that acknowledges the incompetence of medicine in matters of sin. The play evinces the tensions between the stances of science and religion. While the Macbeths strive to persuade themselves of the material origin of their passions, the Doctor's statement emphasizes the spiritual, religious dimension of the problem of the soul's torment as caused by remorse. "It is not," Kocher argues,

that Shakespeare, of all men, fails to see the interaction of body and soul. But to have allowed the Doctor any competence whatsoever in the treatment of Lady Macbeth would have been to obscure the dramatic point he wished to make. And this point, it will bear repeating, was that the source of all her ills was neither natural melancholia nor madness but solely conscience. (1954:345)

Critical interpretation is often the result of critical method, and the two parties reviewed here certainly sustain methodological comparison. In her account of the passions, Paster's procedure throughout her book-length study is to look for, through the examination of "discrete moments and locutions in the play texts" of Shakespeare, "evidence for investigating the phenomenological character of early modern emotion and to contextualize that evidence through reference to early modern treatises, medical texts, natural history, and other literary works" (Paster 2004:23). In stark contrast, Kocher's reading seeks "deep dramatic relevance for the meaning of the play as a whole" -with all the implications this statement has for the understanding of character, plot and intention (1954:349). Reliance on the relevance of discrete moments versus 
attempts at integral readings of plays explains the different conceptions of the early modern self emanating from Paster's and Kocher's work. Kocher insists on the Renaissance writers' idea of an organism aspiring to integral functioning and order but exposed to the vicissitudes of bodily disorder, external action, and sin. Paster emphasizes the absence of an integral self, a notion that is conceptually close to post-modern delineations of the subject like Deleuze and Guattari's BwO (i.e. "Body without Organs"). Thus in Pyrrhus "roasted in wrath and fire," as put by the First Player's tale in Hamlet (2.2.461), Paster suggests that we see "an embodied subject spilling beyond the boundaries of organized selfhood, a subject more like a material site, an intensity of desiring matter or its vacuous absence" (2004:43).

Suggestive as Paster's method and conclusions are, one wonders to what extent an almost exclusive focus on the physiological experience of passionate processes does justice to early modern representations of affect. One may also question an analytical method based only on discrete moments and isolated phrases against more integral considerations of theatrical scripts. In these choices of focus and method one detects a bias against theoreticizing an inner organic consciousness, or against its literary representation in consistent dramatic individualities reclaiming the possession of a distinct inner self not only subjected to unstable emotional outbursts but also capable of aspirations to selfknowledge and self-awareness. I agree with a representation of early modern passions as hardly separable from physiological processes. But this essay resists a reading of early modern dramatic selves as easily reducible to post-modern bodies without organs. Shakespeare might have been wrong when determining in Macbeth that the Queen's mystery would be better unravelled by a divine than a physician. But by doing so he did justice to worldviews current in his time. As a late humanist turning to scepticism and as a tragic dramatist, he also understood that on the stage a physician failing to find out Lady Macbeth's problem was far more effective than a theologian trying to solve it. Shakespearean tragedy portrays a world abandoned by God, but a world nevertheless where humans still believe that this distant God may have the answer to their mysteries. The Doctor in Macbeth is the character that best understands, like Vives and like many others, that, deprived of knowledge of their own ultimate essence as humans are, those 
things called the mind and soul need to be grasped by indirections and intuitions.

\section{Coda: The Visage in the Mind}

In the first act of Othello (1605), Desdemona explains her falling in love with her husband in words that stand as a photographic negative of this paper's argument: "I saw Othello's visage in his mind" (1.3.252). If Duncan fails to find the mind's construction in Cawdor's face, Desdemona thinks she has succeeded in finding Othello's true face in his mind's construction. Her procedure is certainly a surprising one, and not only for all it implies in terms of the racial complexities of the play. Her conviction that Othello's inner self becomes a mirror to his true face suggests that human modes of awareness cannot be disentangled from the passions under whose influence human beings think, feel and act. As imaginative experience, her construction of "Othello's visage" is, like Macbeth's illusion of the "air-drawn dagger," a certain index to her passion's "proper stuff." The extent to which Othello may be a rhetorical exercise in undoing Desdemona's initial construction of her husband's face and mind goes to show that in Shakespearean tragedy the voyage from inward self to outward show can prove as problematic as its opposite. Findings and losses in both directions prove that the unreliable nature of our modes of awareness is due to the gap between our will to know and the partiality of its discoveries.

\section{References}

Aers, David 1992. "A Whisper in the Ear of Early Modernists: or, Reflections on Literary Critics Writing the "History of the Subject.'” Ed. David Aers. Culture and History 1350-1600: Essays on English Communities, Identities and Writing. London: Harvester: 177-202.

Aristotle 1926. Art of Rhetoric. Ed. and trans. J. H. Freese. Cambridge, Ms.: Harvard University Press.

Bamborough, J. B. 1952. The Little World of Man. London: Longmans, Green, and Co., 1952.

Barker, Francis 1984. The Tremulous Private Body: Essays on Subjection. London: Methuen. 
Bartholomeusz, Dennis 1969. Macbeth and the Players. Cambridge: Cambridge University Press.

Baumbach, Sybille 2008. Shakespeare and the Art of Physiognomy. Penrith: Humanities-Ebooks.

Bright, Timothy 1586. A Treatise of Melancholie. London: Thomas Vautrollier.

Camden, Carroll 1941. "The Mind's Construction in the Face." Philological Quarterly 20/3: 400-412.

Campbell, Lily B. 1930. Shakespeare's Tragic Heroes: Slaves of Passion. London: Methuen.

Cefalu, Paul 2004. Revisionist Shakespeare: Transitional Ideologies in Texts and Contexts. New York: Palgrave Macmillan.

Cicero, Marcus Tullius 1577. Four Several Treatises. Trans. Thomas Newton. London.

Cicero, Marcus Tullius 1942. De Oratore. Ed. and trans. H. Rackham. Cambridge, Ms.: Harvard University Press.

Colish, Marcia L. 1962. "The Mime of God: Vives on the Nature of Man." Journal of the History of Ideas 23/1: 3-20

Craig, Hardin 1927. "A Contribution to the Theory of the Renaissance." Philological Quarterly 6: 321-333.

Craig, Hardin 1975 (1952). The Enchanted Glass: The Elizabethan Mind in Literature. Westport: Greenwood Press.

Crawford, A. W. 1915. "O proper stuff! - Macbeth, III, iv, 6o." Modern Language Notes 30/5: 158-160.

Davies, John 1599. Nosce Teipsum. London: Richard Field.

Diehl, Huston 1983. "Horrid Image, Sorry Sight, Fatal Vision: The Visual Rhetoric of Macbeth." Shakespeare Studies 16: 191-204.

Doran, Madeleine 1954. Endeavors of Art: A Study of Form in Elizabethan Drama. Madison: University of Wisconsin Press.

Elam, Keir 1996. "'In What Chapter of his Bosom?': Reading Shakespeare's Bodies." Ed. Terence Hawkes. Alternative Shakespeares, vol. 2. London: Routledge: 140-163.

Florio, John 1598. A World of Words. London: Arnold Hatfield.

Freud, Sigmund 1977 (1916). "Some Character-Types Met with in Psychoanalytic Work." Writings on Art and Literature. Stanford: Stanford University Press: 151-175.

Headlam Wells, Robin 2005. Shakespeare's Humanism. Cambridge: Cambridge University Press.

Hill, Thomas 1571. The Contemplation of Mankind. London. 
Holinshed, Raphael 1586. The Second Volume of Chronicles. London.

Jonson, Ben 1966 (1599). Every Man in His Humour. Ed. Martin SeymourSmith. London: Ernest Benn.

Joseph, B. L. 1951. Elizabethan Acting. London: Oxford University Press

Kerrigan, William 1996. "Macbeth and the History of Ambition." Ed. John O'Neill. Freud and the Passions. University Park: University of Pennsylvania Press: 13-24.

Kirsch, Arthur 1972. The Passions of Shakespeare's Tragic Heroes. Charlottesville: University Press of Virginia.

Kocher, Paul H. 1953. Science and Religion in Elizabethan England. San Marino, Ca.: Huntington Library.

Kocher, Paul H. 1954. "Lady Macbeth and the Doctor." Shakespeare Quarterly 5/4: 341-349.

Machiavelli, Niccolò 1640. The Prince. Trans. Edward Dacres. London.

McDonald, Charles Osborne 1966. The Rhetoric of Tragedy: Form in Stuart Drama. Amherst: The University of Massachusetts Press.

Maus, Katharine Eisaman 1995. Inwardness and Theater in the English Renaissance. Chicago: The University of Chicago Press.

Nonius Marcellus 2003. De compendiosa doctrina. Ed. Wallace M. Lindsay. Munich: Saur.

Paster, Gail Kern 2004. Humouring the Body: Emotions and the Shakespearean Stage. Chicago: The University of Chicago Press.

Paster, Gail Kern, Katherine Rowe, and Mary Floyd Wilson eds. 2004. Reading the Early Modern Passions: Essays in the Cultural History of Emotions. Philadelphia: University of Pennsylvania Press.

Peacham, Henry 1577. The Garden of Eloquence. London.

Quintilian 1921. Institutio Oratoria. Ed. and trans. H. E. Butler. Cambridge, Ms.: Harvard University Press. 3 vols.

Rossky, William 1958. "Imagination in the English Renaissance: Psychology and Poetic." Studies in the Renaissance 5: 49-73.

San Isidoro de Sevilla 1982 (c. 615). Etimologías [Etymologiarum libri]. Ed. José Oroz Reta and Manuel A. Marcos Casquero. Madrid: Biblioteca de Autores Cristianos.

Schoenfeldt, Michael C. 1999. Bodies and Selves in Early Modern England: Physiology and Inwardness in Spenser, Shakespeare, Herbert, and Milton. Cambridge: Cambridge University Press.

Shakespeare, William 1972 (1601). Hamlet. Ed. Harold Jenkins. London: Methuen. 
Shakespeare, William 1997 (1606). Macbeth. Ed. A. R. Braunmuller. Cambridge: Cambridge University Press.

Shakespeare, William 1990 (1606). Macbeth. Ed. Nicholas Brooke. Oxford: Oxford University Press.

Shakespeare, William 1984 (1605). Othello. Ed. Norman Saunders. Cambridge: Cambridge University Press.

Shakespeare, William 1985 (1602). Twelfth Night. Ed. Elizabeth Story Donno. Cambridge: Cambridge University Press.

Sherry, Richard 1550. A Treatise of the Figures of Grammer and Rhetorike. London: Richard Tottel.

Sidney, Philip 1931 (1591). Astrophel and Stella. Ed. Mona Wilson. New York: Nonesuch Press.

Soellner, Rolf 1972. Shakespeare's Patterns of Self-Knowledge. Columbus: Ohio State University Press.

Taylor, Charles 1989. Sources of the Self: the Making of Modern Identity. Cambridge: Cambridge University Press.

Thomson, Peter 1997. "Rogues and Rhetoricians: Acting Styles in Early English Drama." Ed. John D. Cox and David S. Kastan. A New History of Early English Drama. New York: Columbia University Press: 321-335.

Vives, Juan Luis 1612 (1531), De disciplinis. Hi de Curruptis Artibus Doctissimi viri notis, illi de tradendis Disciplinis cuiusdam Studiosi Oxoniensis annotationibus illustrati. Cum indice copioso. London.

Vives, Juan Luis 1782. De anima et vita. Opera Omnia, Tomus III. Ed. Gregorio Mayans. Valencia.

Vives, Juan Luis 1913. On Education: a Translation of the De tradendis disciplinis. Trans. Foster Watson. Cambridge: Cambridge University Press.

Whitney, Geffrey 1997 (1586). A Choice of Emblems. Ed. Peter Daly. The English Emblem Tradition. Index Emblematicus. Vol. 1. Toronto: The University of Toronto Press.

Wright, Thomas 1604 (1601). The Passions of the Minde in Generall. London: Valentine Simmes.

How to cite this article:

Luis Martínez, Zenón. "Macbeth and the passions' "proper stuff"." SEDERI 20 (2010): 71-101.

Author's contact: luis@uhu.es

Submission: 23/02/2009

Acceptance: 02/07/2009 